\title{
Utilization of Keratinolytic Lichtheimia corymbifera AS1 for Degradation of Cattle Hoove - a Slaughter House Waste to Use in Plant Growth
}

\author{
Abirami S 1(D), Ragavi R 1,*(D), Antony V Samrot 2,* (D) \\ Department of Microbiology. Kamaraj College of Arts and Science, Thoothukudi, Tamil Nadu - 628003, India \\ 2 School of Bioscience, Faculty of Medicine, Bioscience \& Nursing, Jalan SP 2, Bandar Saujana Putra, 42610 Jenjarom \\ Selangor \\ * Correspondence: antonysamrot@gmail.com;
}

Scopus Author ID 36100751800

Received: 15.04.2020; Revised: 4.05.2020; Accepted: 6.05.2020; Published: 13.05.2020

\begin{abstract}
In this study, four keratinolytic fungi were isolated from soil. Amongst that one was producing much keratinase, it was identified as Lichtheimia corymbifera AS1. The organism was capable of producing keratinase $(11.8 \mathrm{U} / \mathrm{mL})$ and also of capable degrading $96 \%$ of cattle hooves, a waste obtained from slaughter house in 60 days. The hydrolysate of the hooves degraded medium was used to check its role in seed germination and plant growth. The hydrolysate was found to have much positive influence over the plant growth. Thus, it is helping in degrading waste and helpful for plant growth.
\end{abstract}

Keywords: Lichtheimia corymbifera AS1; hoove; keratinase; plant growth.

(C) 2020 by the authors. This article is an open access article distributed under the terms and conditions of the Creative Commons Attribution (CC BY) license (https://creativecommons.org/licenses/by/4.0/).

\section{Introduction}

Wastes are becoming a major problem all over the world, and they largely contaminate water bodies and land [1-4]. Keratin waste is wasted obtained from slaughterhouses, poultry wastes etc.; it has to be treated before exposure to environment $[5,6]$. Keratins are mostly not soluble in organic solvents including water, weak acids and alkali and resilient to papain and other types of proteases [7]. Korniłłowicz-Kowalska and Bohacz [5] reported that keratins are highly specialized fibrous structural proteins that belong to the superfamily of scleroproteins and are synthesized inside epithelial cells of higher vertebrates and humans. Keratins is different from other structural proteins as it contains more cysteine. Keratin is tough, an outer coat of fibrous insoluble material that serves to prevent the loss of body fluids from animals. Keratin has plentiful cross linking of disulphide bonds [8] and it is naturally occurring protein and abundantly present in hairs, nails, wools, horns, scales, beaks, feathers, hooves, claws and of epithelial cells in the outermost layer of the skin [9].

Keratinases (EC 3.4.21) that can specifically degrade keratin substrates. Keratinase enzyme belongs to hydrolase, metalloproteins and efficient proteolytic enzymes [10]. Insoluble keratinous materials can be degraded by microorganism which produces keratinase enzymes [11]. Most of disease causing and non pathogenic organisms produce keratinases which include fungi and actinomycetes $[12,13]$. The most abundant and highly stable animal proteins on earth are keratin that is recycled by soil Keratinophilic fungi [14]. 
Many of the keratinases isolated from Bacillus and Streptomyces sp. have been recognized as subtilisin like proteases $[7,14]$. Keratinase releases simple amino acids, short peptides and proteins on hydrolysis of the keratinaceous substance [15]. Two alkaline keratinases of Bacillus halodurans PPKS-2 were purified and characterized by Prakash et al [16]. Three keratin specific enzymes of feather isolated Stenotrophomonas maltophilia BBE11-1 were characterized which was cultivated in keratin rich mineral medium. The most vigorous degradation process of keratin and also have the greatest ability to denature the polypeptide chains was found in Fusarium sp 1A [17]. Purpureocillium lilacinum a producer of keratinase has the ability to kill plant parasitic nematodes [18]. Microbial keratinases enzyme has been a huge application potential in tanneries and textile industries [19-21].

The tip of a toe of an ungulate mammal, strengthened by a solid horny, covering is called hooves. Even toed ungulates mammals have an even number of digits are named as Artiodactyls, they are the largest group of mammal. For example cattle, goats. sheep deer and bison. Hooves obtained from slaughter house lead to environment pollution [22]. The strange problem that was present in the reutilization of keratinous wastes of horn / hooves is it cannot be readily digested by any chemical or enzyme treatment [23]. The establishment of microbiological processes for the hydrolysis of these keratinous waste materials under industrially implementable production conditions to obtain high protein feed ingredients. The key goal of this work is to screen and isolate keratinolytic fungi from soil and to evaluate hooves degradation in pot study. The hydrolysates of hooves were also used for plant growth promotion.

\section{Materials and Methods}

\subsection{Materials used.}

All chemicals and reagents required for the experimental works were of an analytical grade. All the growth media and reagents were purchased from HiMedia Chemicals, India. Hooves were collected from slaughter house, Melapalayam, Tirunelveli, Tamil Nadu, India.

\subsection{Collection of hooves and isolation of fungi.}

Hooves were cleaned, washed with distilled water and shadow dried. Pieces were buried under garden soil up to $10 \mathrm{~cm}$ depth. After one month, buried hooves were collected in sterile sealed containers, from which to isolate indigenous keratinolytic fungi. Buried hooves were washed with $50 \%$ acetone except for the region of mycelial growth and they were placed on Petri plates containing Rose Bengal agar medium, then incubated at $37{ }^{0} \mathrm{C}$ for 5 days. Every individual colonies were carefully streaked on Rose Bengal agar plates, incubated for 2 days and that culture was used for further screening of proteolytic activity.

\subsection{Production of keratinase enzymes by submerged cultivation.}

$1-2 \mathrm{~mm}$ sized cut dried hooves were defatted using $\mathrm{CHCl}_{3}: \mathrm{CH}_{3} \mathrm{OH}(1: 1)$ for $30 \mathrm{~min}$ at $37{ }^{\circ} \mathrm{C}$ [24]. Then, they were immersed with detergent up to $16 \mathrm{~h}$ at $42{ }^{\circ} \mathrm{C}$, followed with washing for five times in distilled water and dried in hot air oven at $60{ }^{\circ} \mathrm{C}$ for $48 \mathrm{~h}$. The cultivation medium was prepared according to the method of Bhange et al [25] with some modifications and contained small pieces of hooves $(15 \mathrm{~g} / \mathrm{L}), \mathrm{K}_{2} \mathrm{HPO}_{4}(1.5 \mathrm{~g} / \mathrm{L})$, $\mathrm{MgSO}_{4} \cdot 7 \mathrm{H}_{2} \mathrm{O}(0.05 \mathrm{~g} / \mathrm{L}), \mathrm{CaCl}_{2}(0.025 \mathrm{~g} / \mathrm{L}), \mathrm{FeSO}_{4} \cdot 7 \mathrm{H}_{2} \mathrm{O}(0.015 \mathrm{~g} / \mathrm{L})$ and $\mathrm{ZnSO}_{4}(0.005 \mathrm{~g} / \mathrm{L})$. 
$100 \mathrm{~mL}$ of the above medium was taken in Erlenmeyer flasks $(250 \mathrm{~mL})$ and autoclaved. The inoculum was prepared by suspending spores from Rose Bengal medium in 10ml of Tween 80 $(0.1 \%)(\mathrm{v} / \mathrm{v})$. Then, $1 \mathrm{~mL}$ of this suspension containing $10^{6}-10^{7}$ spores was inoculated into the experimental flask. Control flask without fungal inoculum was also maintained. All the flasks were shaker incubator for 5 days with $120 \mathrm{rpm}$ and $30{ }^{\circ} \mathrm{C}$. After this period of incubation, culture medium was centrifuged at $10000 \mathrm{rpm}$ and supernatant was checked for keratinolytic activity.

\subsection{Screening of proteolytic activity of fungal isolates.}

The proteolytic activity was screened by using sterile skimmed milk agar medium. Size of $1 \mathrm{~mm}$ diameter well was made on the surface of skimmed milk plates. $20 \mu \mathrm{L}$ of culture supernatant was poured into the well, incubated for $24 \mathrm{~h}$ at $37{ }^{\circ} \mathrm{C}$. Culture was centrifuged and the supernatant was checked for the highest zone of clearance, the organism which showed the highest zone of clearance was selected for further study.

\subsection{Keratinase assay.}

Keratinolytic activity was concluded as follows. Keratin powder $(20 \mathrm{mg})$ mixed in Tris$\mathrm{HCl}$ buffer $(100 \mathrm{mM}, \mathrm{pH} 7.8 ; 3.8 \mathrm{ml})$ was incubated with above obtained crude enzymatic extract $(0.2 \mathrm{ml})$ for $1 \mathrm{~h}$ at $37{ }^{\circ} \mathrm{C}$. after incubation, the samples were kept at $4{ }^{\circ} \mathrm{C}$ for $10 \mathrm{~min}$ and then centrifuged for $10 \mathrm{~min}$ at $10,000 \mathrm{rpm}$ at $4^{\circ} \mathrm{C}$. The absorbance of the supernatant at $280 \mathrm{~nm}$ was measured by spectrophotometry against a blank. Unit of enzyme activity was determined as prescribed [26].

\subsection{Identification of isolated fungi.}

The highest enzyme producing fungi was further used in this study. To visualize fungal morphology, the isolated fungi were stained with Lactophenol cotton blue and observed it under microscope. Fungal DNA was isolated [27], further purified by isoamyl alcohol: chloroform and amplified with forward and reverse primers ITS1 5'TCCGTAGGTGAACCTGCGG 3' and ITS4 5'TCCTCCGCTTATTGATATGC3' respectively. PCR was done with the condition prescribed by Martin and Rygiewicz [28]. The obtained amplified product was sequenced (ABI 3730xl sequencer, Applied Biosystems). The sequence was submitted in GenBank.

\subsection{Degradation of hooves in the liquid medium.}

The hooves were sterilized with chloroform methanol $(1: 1, \mathrm{v} / \mathrm{v})$ and washed with distilled water. They were sundried, ground with mixer to obtain coarse powder. It was further used for assay of keratinolytic activity. $10 \%(\mathrm{v} / \mathrm{v})$ hooves in the form of coarse pieces added in the medium containing $(\mathrm{g} / 100 \mathrm{~mL})-\mathrm{KH}_{2} \mathrm{PO}_{4}-0.07, \mathrm{~K}_{2} \mathrm{HPO}_{4}-0.03, \mathrm{MgSO}_{4} .5 \mathrm{H}_{2} \mathrm{O}-0.05$, $\mathrm{FeSO}_{2} . \mathrm{H}_{2} \mathrm{O}-0.001, \mathrm{ZnSO}_{4}-0.0001$, and $\mathrm{MnCl}_{2}-0.0001$ at a $\mathrm{pH}$ 8.5. The medium was sterilized. The selected fungus was inoculated into the medium and incubated on rotating shaker of 150 rpm at $25{ }^{\circ} \mathrm{C}$ upto $6^{\text {th }}$ months. A set of fungal uninoculated flasks was maintained as control. During the incubation period, $5 \mathrm{~mL}$ medium was collected at regular time interval inside laminar chamber and it was centrifuged, supernatant was determined for keratinolytic activity by measuring sulpholysis due to the degradation of keratin. 


\subsection{Determination of sulphate.}

Sulphate was determined by following the method of Morante [29]. Here standard graph was made having standard solution of $\mathrm{Na}_{2} \mathrm{SO}_{4}$ where the reaction was as follows $-5 \mathrm{~mL}$ of sample (culture supernatant) was added with $\mathrm{BaCl}_{2}-1 \mathrm{~g}, 2 \mathrm{~mL}$ of gum Acacia $(0.25 \% \mathrm{w} / \mathrm{v})$ and it was made to $25 \mathrm{ml}$ using Milli Q water. Kept undisturbed for $15 \mathrm{~min}$ and then read at $470 \mathrm{~nm}$.

\subsection{Degradation of hooves by pot method.}

Two pots with size of $45 \mathrm{~cm}$ x $12 \mathrm{~cm}$ were used for hooves degradation study. Seven pots were taken and spread with the sterile soil (packed and autoclaved garden soil) evenly into the pot. About $52.3 \mathrm{~g}$ hooves were buried into the soil under the depth of $30 \mathrm{~cm}$. Experimental pot was inoculated with isolated keratinolytic fungi of spore suspensions of $2 \times 10^{8}$ from 5 days old inoculum. Pot without fungal inoculation serves as control. The pots were covered and incubated at room temperature for 6 months. Both the pots were regularly sprayed with sterile water with the purpose of maintaining the moisture content of pot soil. Every month hooves sample from one pot was taken out and measured for the hooves weight (g). Degree of degradation of buried hooves samples (DD)was calculated as follows -

$$
\operatorname{DD}(\%)=\frac{(\text { Initial Weight- Loss of Weight }) .}{\text { Initial weight }} \times 100
$$

\subsection{Growth promotion assays of plant using hooves hydrolysates.}

2.10.1. Seed germination assay.

Ability of hydrolysates of hooves to promote seed germination was studied by standard seed germination assay. High quality Vigna mungo L seeds were purchased from Agriculture University, Vallanadu, Thoothukudi. Surface sterilization Vigna mungo L seeds were done with sodium hypochlorite $(1.0 \% \mathrm{v} / \mathrm{v})$ for $10 \mathrm{~min}$. Then seeds were washed with sterile distilled water and dried. Two sets with thirty seeds each were incubated with $10 \mathrm{~mL}$ of sterilized broth and hooves hydrolysates respectively for $4 \mathrm{~h}$ at room temperature. Different sets of treated seeds were sown in different pots and watered it regularly at $37^{\circ} \mathrm{C}$ in the dark. Daily observation of seeds germination was done up to 3 days. The number of seeds germinated was tabulated and calculated the percentage of germination for each treatment.

2.10.2. Effect of hooves hydrolysate on the growth of Vigna mungo L plant.

Vigna mungo L seeds were surface sterilized by immersing in $70 \%$ ethanol for 5 min and washed twice with water, following that they were immersed in $1.0 \%$ sodium hypochlorite for 10 min followed by three washes with sterile water. Seeds were soaked in water for 4 days at $28{ }^{\circ} \mathrm{C}$ in the dark room. Then, 10 germinated seeds/pot was transferred. The entire set up was placed on a green house at $25{ }^{\circ} \mathrm{C}$ with enough photoperiod. During the experiment, one pot was acting as control where it was irrigated with water alone and the experimental pot was irrigated along with hooves hydrolysate three times/ day for 15 days. After 15 days, all pots were irrigated with distilled water regularly. After 21 days, the plants were carefully uprooted from the pots and the root surface was cleaned carefully with water. Root length, shoot length, weight of plant and number of internode were recorded. 


\section{Results and Discussion}

After one month, buried hooves samples were taken for keratinolytic fungal isolation. Four different fungi morphology was observed on the Rose Bengal Agar Medium. Fungi I showed white cottony growth, Fungi II showed green cottony growth, Fungi III showed black mycelial morphology and Fungi IV showed light green mycelial morphology. They were isolated from the buried hooves sample (Fig.1). After that, proteolytic activity of these fungi was analyzed.
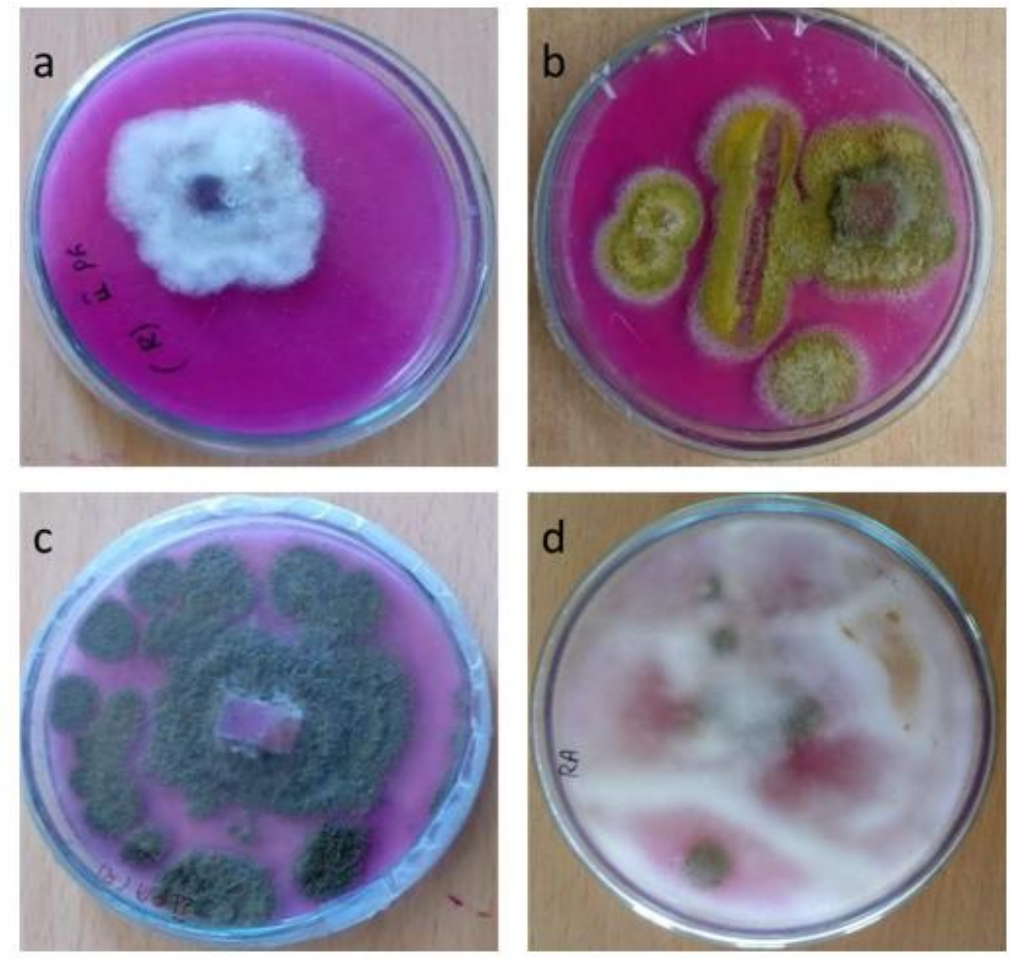

Figure 1. Fungi isolated from soil a) HDF1 b) HDF2 c) HDF3 d) HDF4.

Table 1 Zone of clearance of culture supernatant of isolated fungi on Skim Milk Agar Medium Among the four fungi, HDF1 (60 mm) and HDF4 (39 mm) showed greatest zone of clearance around the well of Skim Milk Agar Medium. They were selected for the production of keratinase enzymes. Santos et al. [12] reported that several pathogenic and non pathogenic keratinolytic species belonging to fungi. Normally keratinous rich soil induces the growth and occurrence of keratinophilic fungi [30].

Table 1. Zone of clearance by culture supernatant of isolated fungi on skim milk agar medium.

\begin{tabular}{l|c|c} 
S:No & Fungal Isolates & Zone of clearance $(\mathrm{mm})$ \\
\hline 1 & HDF1 & $60 \mathrm{~mm}$ \\
\hline 2 & HDF2 & $1.7 \mathrm{~mm}$ \\
\hline 3 & HDF3 & $0.5 \mathrm{~mm}$ \\
\hline 4 & HDF4 & $39 \mathrm{~mm}$
\end{tabular}

$\mathrm{HDF}_{1}$ showed the highest keratinase activity $(11.7 \mathrm{U} / \mathrm{ml})$ after incubation of 4 days at pH 5 than $\mathrm{HDF}_{4}$ (5.4mm) (Fig 2). Lactophenol cotton blue staining of HDF1 showed prominent sporongiospore (Fig.3). This fungus was undergone molecular identification by ITS region, the organism was found to be Lichtheimia corymbifera AS1 (GenBank Accession number MT269276). Keratinophilic fungi are capable of using keratin as the only source of C, N, S and energy for their growth [14]. Sharma and Rajak [31] reported that many keratinophilic fungi are found in Indian soils and there is a requirement to further taxonomic classification and 
ecological studies of this interesting group of organisms. The keratinolytic activity of L.corymbifera AS1 showed maximum on the 4 days of fermentation. The keratinolytic activity of L.corymbifera was showed the highest $(11.8 \mathrm{U} / \mathrm{ml})$ after 4 days. After that, keratinolytic activity was gradually decreased (Fig. 4). Similarly, El-Ghonemy and Hamed Ali [32] reported that the highest keratinase production of Aspergillus sp. DHE7 was observed after four days of incubation using $2 \%$ of chicken feathers as substrate in submerged conditions. A. fumigatus showed optimal activity after $72 \mathrm{~h}$ [33]. but contradictorily, Mazotto et al. [26] reported the lowest feather degrading keratinolytic activity by A.niger after four days $(21.3 \mathrm{U} / \mathrm{ml})$ in submerged fermentation.

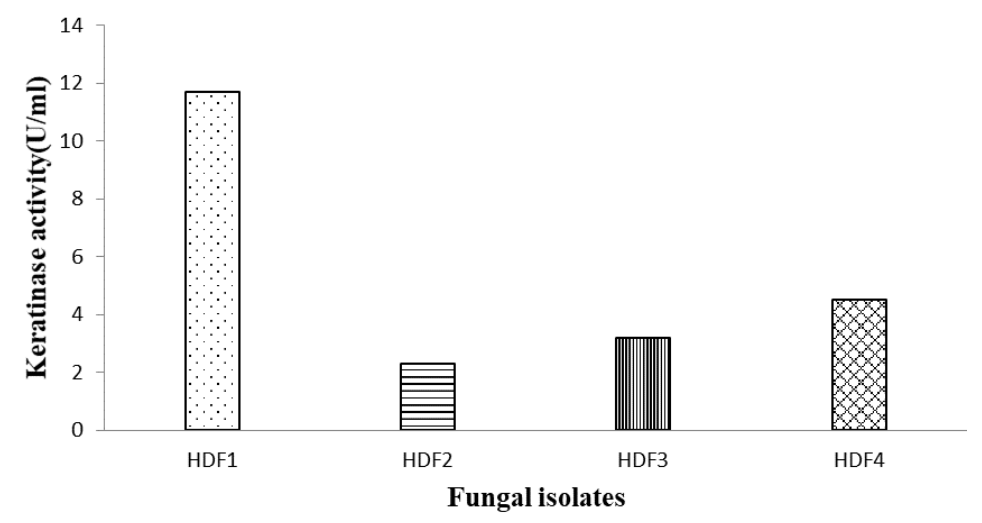

Figure 2. Keratinolytic activity of isolated fungi.

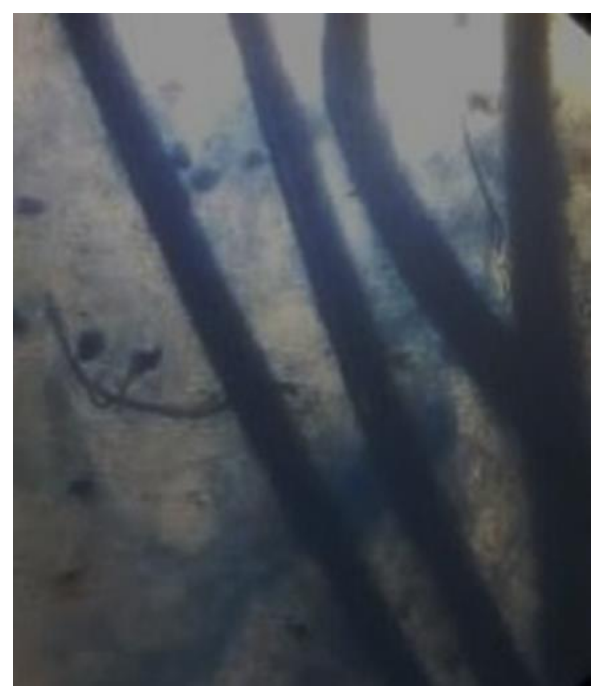

Figure 3. Lactophenol cotton blue staining of the isolated culture.

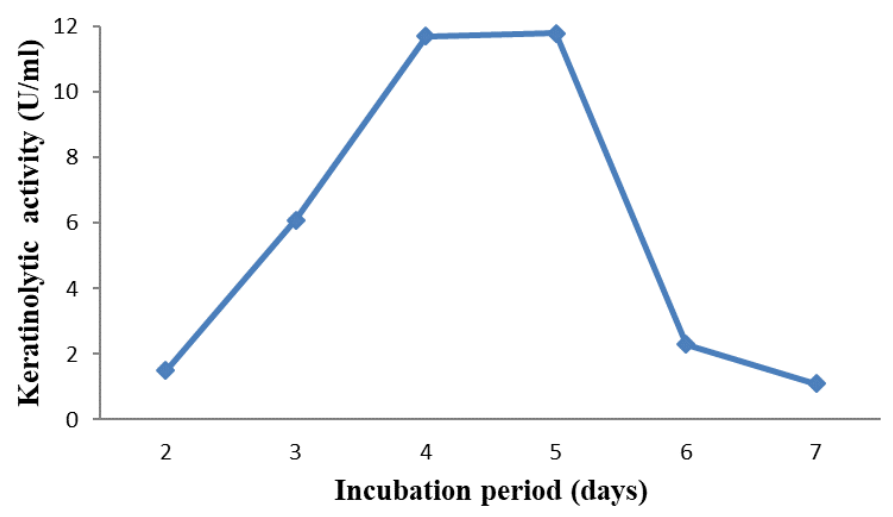

Figure 4. Keratinolytic activity of Lichtheimia corymbifer AS1. 
Using keratinase enzymes, keratinous waste products like hair, feathers, skin, fur, animal hooves, horns can be degraded and can be used in biodegradable films, coatings and glues etc.. this bioconversion of keratinous waste products into value added products using keratinase enzyme could be an environmental friendly technology [34]. keratinase enzyme is used in anti-dandruff shampoos which helps in dead cells and infections caused by fungi / warts $[35,36]$.

Hooves degradation in liquid medium was conducted from August to January months. Hooves degradation was measured by sulphate liberation on media because hooves keratin have a high amount of sulphur containing amino acids. Fig. 5 showed sulphate concentration was maximum $(28 \mathrm{mg})$ in the $5^{\text {th }}$ month.

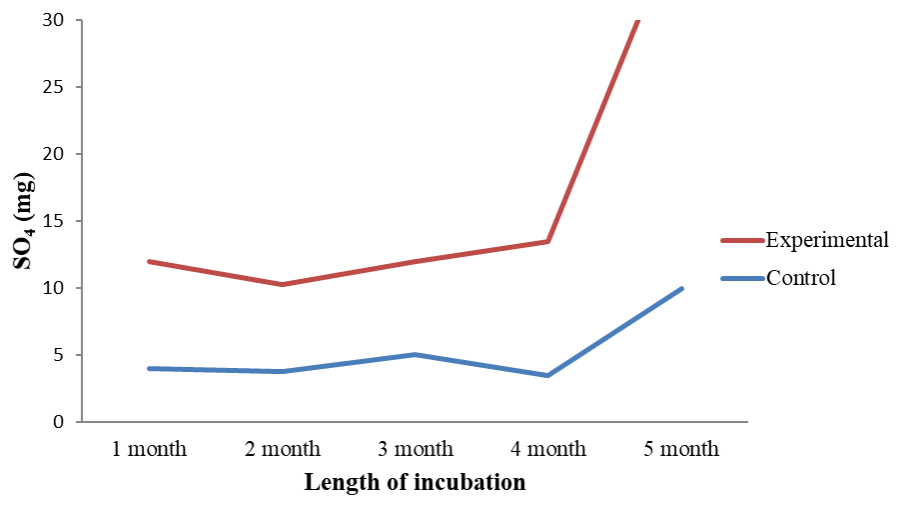

Figure 5. Sulphate estimation of hooves degradation in liquid media.

Pot study of hooves degradation was analyzed by weight loss of the hooves. Degree of degradation of hooves was effectively occurred upto $96 \%$ in $6^{\text {th }}$ month (Table 2 ). The effect of hooves hydrolysates on Vigna mungo L seed germination was shown in Table 3. At $72 \mathrm{~h}$ of incubation, seed germination increased effectively when the seeds were treated with the hooves hydrolysates than control. After 21 days, hooves hydrolysate treated Vigna mungo L seedling showed excellent growth parameters compared to control. Fig. 6 showed growth parameters of hooves hydrolysates treated Vigna mungo L seedling. Hooves hydrolysates contain high protein content that induced plant growth effectively. Fertilizers with sulfur containing amino acid have been reported to enhance yield of plant [37]. Brandelli et al. [38] reported that hooves hydrolysate induced seed germination and seedling growth. Similarly, the present work also hooves hydrolysates induced Vigna mungo $L$ seedling growth effectively due to the high protein content of hooves hydrolysate. Kshetri et al [39] also showed the phytostimulant activity of keratinase producing actinobacteria. Uses of these keratinase producing organisms are well reported [40-42]. There are several reports stating that microorganisms were used for producing biotechnological products [43-44].

Table 2. Determination of Hooves degradation (pot study).

\begin{tabular}{l|l|c|c|c} 
S. no & Month & Original weight $(\mathrm{g})$ & Weight of the sample $(\mathrm{g})$ & \% Degree of Degradation \\
\hline 1. & August & 52.3 & 50.1 & 5.1 \\
\hline 2. & September & 52.3 & 47.8 & 8.6 \\
\hline 3. & October & 52.3 & 30.2 & 42 \\
\hline 4. & November & 52.3 & 13 & 75 \\
\hline 5. & December & 52.3 & 3.9 & 93 \\
\hline 6. & January & 52.3 & 3 & 96
\end{tabular}


Table 3. Effect of hooves hydrolysates on seed germination.

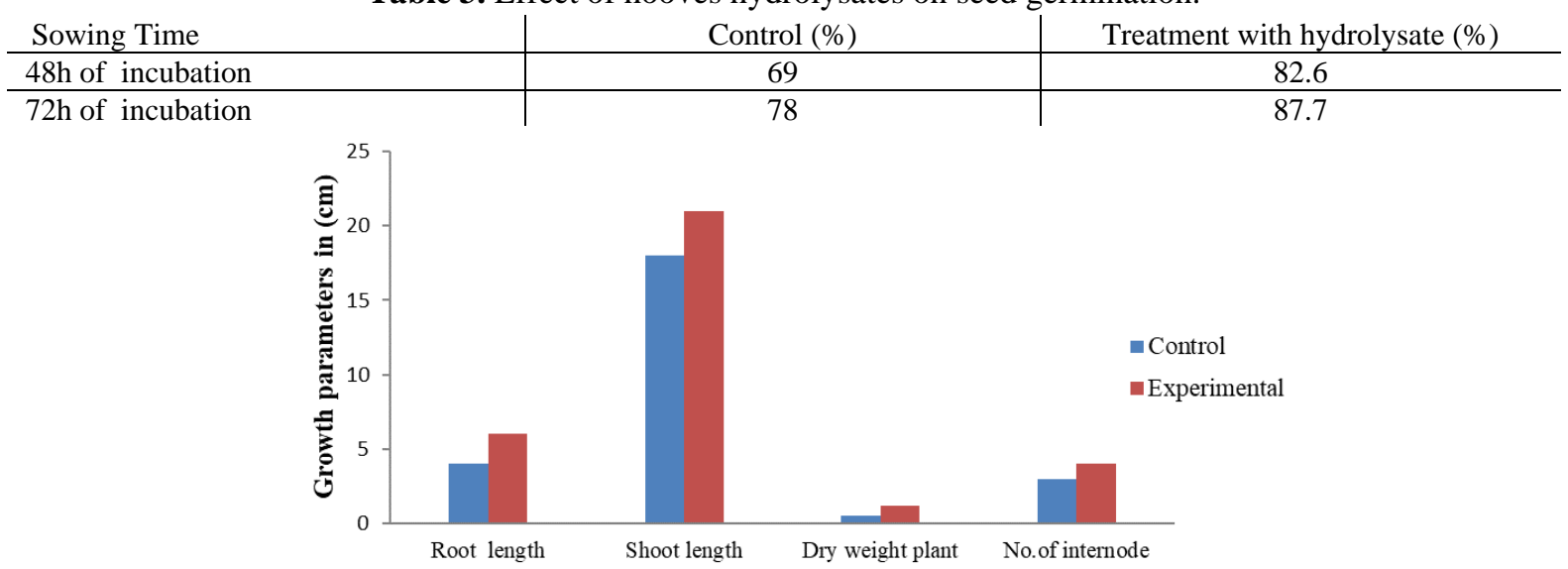

Figure 6. Effect of hooves hydrolysate on seedling growth of black gram after 21 days.

\section{Conclusions}

In the present research work, isolation of keratinolytic fungi from buried hooves was successfully carried out. Four keratinolytic fungi were isolated and one was producing more than others. That fungi were identified as L.corymbifera AS1 and it has a maximum keratinase activity of $11.8 \mathrm{U} / \mathrm{mL}$ in $4^{\text {th }}$ day. This organism was degrading the hoove by $96 \%$. The hydrolysate was found to enhance the seed germination and growth promotion of the plant chosen in this study. This study provides important leads bioremediation of hooves wastes and its application in plant growth stimulation.

\section{Funding}

This research received no external funding.

\section{Acknowledgments}

The authors acknowledge the Management, Kamaraj College of Arts and Science for giving lab to perform this work.

\section{Conflicts of Interest}

The authors declare no conflict of interest.

\section{References}

1. Bhavya, K.S.; Raji, P.; Selvarani, A.J.; Samrot, A.V.; Javad, P.T.M.; Appalaraju, V.V.S.S. Leather processing, its effects on environment and alternatives of chrome tanning. International Journal of Advanced Research In Engineering And Technology (IJARET) 2019, 10, 69-79, https://doi.org/10.34218/IJARET.10.6.2019.009.

2. Samrot, A.V.; Sahithya, C.S.; Selvarani, A.J.; Pachiyappan, S.; Kumar. S.S. Surface-Engineered SuperParamagnetic Iron Oxide Nanoparticles For Chromium Removal. Int. J. Nano Med. 2019, 2019, 81058119. https://doi.org/10.2147/IJN.S214236.

3. Raji, P.; Samrot, A.V.; Bhavya, K.S.; Sharan, M.; Priya, S.; Paulraj, P. Greener Approach for Leather Tanning Using Less Chrome with Plant Tannins and Tannins Mediated Nanoparticles. J Clust Sci. 2019. 30, 1533-1543, https://doi.org/10.1007/s10876-019-01597-6.

4. Samrot, A.V.; Shobana, N.; Sruthi, D.P.; Sahithya, C.S. Utilization of chitosan coated superparamagnetic iron oxide nanoparticles for chromium removal. Appl. Water Sci. 2018, 8, 192, https://doi.org/10.1007/s13201-018-0841-4.

5. Korniłłowicz-Kowalska, T.; Bohacz, J. Biodegradation of keratin waste: Theory and practical aspects. Waste Manag. 2011, 31, 1689-701, https://doi.org/10.1016/j.wasman.2011.03.024. 
6. Martínez-Alvarez, O.; Chamorro, S.; Brenes, A. Protein hydrolysates from animal processing by-products as a source of bioactive molecules with interest in animal feeding: A review. Food Res. Int. 2015, 73, 204212, https://doi.org/10.1016/j.foodres.2015.04.005.

7. Daroit, D.J.; Brandelli, A. A current assessment on the production of bacterial keratinases. Crit. Rev. Biotechnol. 2013, 34, 372 - 384, https://doi.org/10.3109/07388551.2013.794768.

8. Prasanna, I.; Vimalan, S.; Lavanya, V.; Selvi, A.T. Study on Keratinophilic and keratinolytic fungi isolated from birds and animals hairs. Biosciences Biotechnology Research Asia. 2011, 8, 633-640.

9. Friedrich, J.; Gradisar, H.; Mandin, D.; Chaumont, J.P. Screening fungi for synthesis of keratinolytic enzymes. Appl. Microbiol. 1999, 28, 127-130, https://doi.org/10.1046/j.1365-2672.1999.00485.x.

10. Farag, A.; Hassan, M. Purification, characterization and immobilization of a keratinase from Aspergillus oryzae. Enzyme Microb. Technol. 2004, 34, 85-93, https://doi.org/10.1016/j.enzmictec.2003.09.002.

11. Sousa, M. Souza, O.; Maciel, M.; Cruz, R.; Rego, M.G.; Magalhaes, O.; Pessoa-Junior, A.; Porto, A.; SouzaMotta, C. Keratinolytic potential of fungi isolated from soil preserved at the Micoteca URM. European J. Biotechnol. Biosci. 2015, 3, 10-15.

12. Santos, R.M.D.B.; Firmino, A.A.; de Sa', C.M.; Felix, C.R. Keratinolytic activity of Aspergillus fumigatus Fresenius. Curr Microbiol 1996, 33, 364-370, https://doi.org/10.1007/s002849900129.

13. Malviya, H.K.; Rajak, R.C.; Hasija, S.K. Synthesis and regulation of extracellular keratinase in three fungi isolated from the grounds of a gelatin factory, Jabalpur, India. Mycopathologia 1992, 120, 1-4, https://doi.org/10.1007/BF00578494.

14. Sharma, R.; Devi, S. Versatility and commercial status of microbial keratinase a review. Rev. Environ. Sci. Bio. 2018, 17, 19-45, https://doi.org/10.1007/s11157-017-9454-X.

15. Contesini, F.J.; Melo, R.R.; Sato, H.H. An overview of Bacillus proteases from production to application. Crit. Rev. Biotechnol. 2018, 38, 321-334, https://doi.org/10.1080/07388551.2017.1354354.

16. Prakash, P.; Jayalakshmi SK, Sreeramulu K. Purification and characterization of extreme alkaline, thermostable keratinase, and keratin disulfide biotechnology reductase produced by Bacillus halodurans PPKS-2. Appl. Microbiol. Biotechnol. 2010. 87, 625-633, https://doi.org/10.1007/s00253-010-2499-1.

17. Calin, M.; Constantinescu-Aruxandei, D.; Alexandrescu, E.; Raut, I.; Doni, M.B.; Arsene, M.L.; Oancea, F.; Jecu, L.; Lazar, V. Degradation of keratin substrates by keratinolytic fungi. Electron. J. Biotechn. 2017, 28, 101-112, https://doi.org/10.1016/j.ejbt.2017.05.007.

18. Mo, C.; Xie, C.; Wang, G.; Liu, J.; Hao Q, Xiao X, Xiao Y. Genome-wide identification and characterization of the cyclophilin gene family in the nematophagous fungus Purpureocillium lilacinum. Int. J. Mol. Sci. 2019, 20, 2978; https://doi.org/10.3390/ijms20122978.

19. Ramnani, P, Singh, R.; Gupta, R. Keratinolytic potential of Bacillus licheniformis RG1 structural and biochemical mechanism of feather degradation. Can. J. Microbiol. 2015, 51,191-196, https://doi.org/10.1139/w04-123.

20. Giongo, J.L.; Lucas, F.S.; Casarin, F.; Heeb, P.; Brandelli, A. Keratinolytic proteases of Bacillus species isolated from the Amazon basin showing remarkable de-hairing activity. World J. Microbiol. Biotechnol. 2007, 23, 375-382, https://doi.org/10.1007/s11274-006-9234-1.

21. Macedo, A.J.; da Silva, W.O.; Gava, R.; Driemeier, D.; Henriques, J.A.; Termignoni, C. Novel keratinase from Bacillus subtilis S14 exhibiting remarkable dehairing capabilities. Appl. Environ. Microbiol. 2005, 71, 594-496, https://doi.org/10.1128/AEM.71.1.594-596.2005.

22. Kumari-Chittturi, C.M.C.; Lakshmi, J.P.; Lakshmi, V.V. Microbial Keratinases and their Applications. International Journal of Scientific and Engineering Research. 2015, 6, 173-176.

23. Laba, W.; Choinska, A.; Rodziewicz, A.; Piegza, M. Keratinolytic abilities of Micrococcus luteus from poultry waste. Braz. J. Microbiol. 2015, 46, 691-700, https://doi.org/10.1590/S1517-838246320140098.

24. Wawrzkiewicz, K.; Lobarzewski, J.; Wolski, T. Intracellular keratinase of Trichophyton gallinae. Journal of Medical and Veterinary Mycology 1987, 25, 261-268.

25. Bhange, K.; Chaturvedi, V.; Bhatt, R. Feather degradation potential of Stenotrophomonas maltophilia KB13 and feather protein hydrolysate (FPH) mediated reduction of hexavalent chromium. 3 Biotech. 2016, 6, 42, https://doi.org/10.1007/s13205-016-0370-5.

26. Mazotto, A.M.; Couri, S.; Damaso, M.; Vermelho, A.B. Degradation of feather waste by Aspergillus niger keratinases: Comparison of submerged and solid-state fermentation. Int. Biod. Biod. 2013, 85, 189-195, https://doi.org/10.1016/j.ibiod.2013.07.003

27. Zhang, Y.J.; Zhang, S.; Liu, X.Z.; Wen, H.A.; Wang, M. A simple method of genomic DNA extraction suitable for analysis of bulk fungal strains. Lett. Appl. Microbiol. 2010. 51, 114-118, https://doi.org/10.1111/j.1472-765X.2010.02867.x.

28. Martin, K.J.; Rygiewicz, P.T. Fungal-specific PCR primers developed for analysis of the ITS region of environmental DNA extracts. BMC Microbiol. 2005, 5, 28, https://doi.org/10.1186/1471-2180-528.

29. Morante, C. Determination of plant sulphur and sulphate-sulphur by flow-injection analysis using a two-line manifold. Analytrca Chlmlca Acta. 1991. 249, 479-488, https://doi.org/10.1016/S0003-2670(00)83022-6.

30. Moallaei, H.; Zaini, F.; Pihet, M.; Mahmoudi, M.; Hashemi, J. Isolation of keratinophilic fungi from soil samples of forests and farm yards. Iranian Journal of Public Health. 2006. 35, 62-69. 
31. Sharma, R.; Rajak, R.C. Keratinophilic Fungi: Nature's Keratin Degrading Machines! Their Isolation, Identification and Ecological Role. Resonance 2003, 28-33, https://doi.org/10.1007/BF02837919.

32. El-Ghonemy, D.H.; Ali, T.H. Optimization of Physico-Chemical Parameters for Hyper Keratinase Production from a Newly Isolated Aspergillus sp. DHE7 using Chicken Feather as SubstrateManagement of Biowaste. Journal of Applied Pharmaceutical Science 2017. 7, 171-178, https://doi.org/10.7324/JAPS.2017.70923.

33. Noronha, E.F.; de Lima, B.D.; de Sa, C.M.; Felix, C.R. Heterologous production of Aspergillus fumigatus keratinase in Pichia pastoris. World J. Microbiol. Biotechnol. 2002, 18, 563-568, https://doi.org/10.1023/A:1016341702908.

34. Sharma, S.; Gupta, A. Sustainable Management of Keratin Waste Biomass: Applications and Future Perspectives. Braz. Arch. Biol. Technol. 2016, 59, https://doi.org/10.1590/1678-4324-2016150684.

35. Matikevicience V, Masiliunience D and Grigiskis S. Degradation of keratin containing wastes by Bacteria with keratinolytic activity. Proceedings of the 7th International Scientific and Practical Conference. Environment Technology Resources 2009, 1, 284-289.

36. Vigneshwaran, C.; Shanmugam, S.; Kumar, T.S. Screening and Characterization of Keratinase from Bacillus licheniformis Isolated From Namakkal poultry Farm. Researcher. 2010; 2, 89-96.

37. Shekari, G.; Javanmardi, J. Application of Cysteine, Methionine and Amino Acid Containing Fertilizers to Replace Urea: The Effects on Yield and Quality of Broccoli. Adv. Crop Sci. Tech. 2017, 5, 283, https://doi.org/10.4172/2329-8863.1000283.

38. Brandelli, A.; Sala, L.; Kalil, S.J. Microbial enzymes for bioconversion of poultry waste into added value products. Food Res Int. 2015, 73, 3-12, https://doi.org/10.1016/j.foodres.2015.01.015.

39. Kshetri, P.L, Roy, S.S.; Sharma, S.K.; Singh, T.S.; Ansari, M.A.; Sailo, B.; Singh, S.; Prakash, N. Feather degrading, phytostimulating, and biocontrol potential of native actinobacteria from North Eastern Indian Himalayan Region. J Basic Microbiol. 2018, 58, 730-738, https://doi.org/10.1002/jobm.201800169.

40. Li, Q. Progress in Microbial Degradation of Feather Waste. Front. Microbiol 2019, 05, https://doi.org/10.3389/fmicb.2019.02717.

41. Tamreihao, K.; Mukherjee, S.; Khunjamayum, R.; Devi, L.J.; Asem, R.S.; Ningthoujam, D.S. Feather degradation by keratinolytic bacteria and biofertilizing potential for sustainable agricultural production. Journal of basic microbiology 2018, https://doi.org/10.1002/jobm.201800434

42. Oluwaseun, A.C., Phazang, P.; Sarin, N.B. Production of ecofriendly biofertilizers produced from crude and immobilized enzymes from Bacillus subtilis $\mathrm{CH} 008$ and their effect on the growth of Solanum lycopersicum. Plant Archives 2018, 18, 1455-1462.

43. Halevas, E.G.; Pantazaki, A.A. Advances in the optimized synthesis of biotechnologically valuable products from bioengineered microbial cell factories. Biointerface Research in Applied Chemistry 2018, 8(4), 3463 3482.

44. Fwazi, S.; Ali, A. Performance of cellulose acetate propionate in polycaprolactone and starch composites: biodegradation and water resistance properties. Biointerface Research in Applied Chemistry. 2020, 10(3), 5382 - 5386. https://doi.org/10.33263/BRIAC103.382386. 